Sains Malaysiana 46(2)(2017): 267-274

http://dx.doi.org/10.17576/jsm-2017-4602-11

\title{
Prevalence of Hearing Loss and Hearing Impairment among Small and Medium Enterprise Workers in Selangor, Malaysia
}

(Kelaziman Kehilangan Pendengaran dan Kecelaan Pendengaran antara Pekerja Perusahaan Kecil dan Sederhana di Selangor, Malaysia)

\author{
SAM W.Y., ANITA A.R.,* HaYATI K.S., HASLINDA A. \& Lim C.S.
}

\begin{abstract}
Factories and Machinery (Noise Exposure) Regulation 1989 has always demanded employer to protect workers from noise exposure $\geq 85 \mathrm{~dB}$. However, noise induced hearing loss (NIHL) has been the highest notifiable occupational health issue among Malaysian workers in 2014. A cross-sectional study aimed to investigate the prevalence of hearing loss (HL) among 146 adult manufacturing workers with noise exposure $\geq 85 \mathrm{~dB}$ was carried out in Selangor. Pure tone audiometry and a validated questionnaire were used to determine the hearing status and information of the respondents. The results showed that the prevalence of $H L$ was $73.3 \%$ and the prevalence of hearing impairment was $23.3 \%$. Male workers (63.0\%) had higher prevalence of HL than female workers (36.4\%). Mean hearing threshold levels of $H L$ respondents were significantly higher than respondents with normal hearing. It was discovered that among workers with employment of more than 10 years, $>80 \%$ of them suffered from HL. Association between employment years and hearing condition (normal, non-bilateral and bilateral $H L$ ) was statistically significant, $\chi(4)=10.51, \mathrm{p}=0.033$, with Kendall tau-c correlation showing positive and weak $(\mathrm{p}=0.18)$ association. Highest HL cases were found at 4 and $6 \mathrm{kHz}$. World Health Organisation and Factories and Machinery (Noise Exposure) Regulation 1989 classification on degree of hearing impairment showed slight to moderate hearing impairment among the respondents and both standards did not differ much (8.9\% vs 6.9\%, respectively). As a conclusion, prevalence of hearing loss and hearing impairment among manufacturing workers were high. Age, male sex, monthly salary and employment years were possible influencing factors.
\end{abstract}

Keywords: Audiometric test; degree of hearing impairment; manufacturing workers; noise induced hearing loss; prevalence

\section{ABSTRAK}

Peraturan Kilang dan Jentera (Pendedahan Bunyi Bising) 1989 sentiasa menuntut majikan untuk melindungi pekerja daripada pendedahan bunyi bising $\geq 85 \mathrm{~dB}$. Walau bagaimanapun, kehilangan pendengaran akibat bunyi bising (KPABB) masih merupakan isu kesihatan pekerjaan yang paling banyak dilaporkan terjadi dalam kalangan pekerja di Malaysia pada tahun 2014. Suatu kajian keratan lintang yang bertujuan untuk mengkaji kelaziman kehilangan pendengaran (HL) dalam kalangan 146 pekerja dewasa sektor pengilangan yang didedahkan kepada bunyi bising $\geq 85$ dB telah dijalankan di Selangor. Ujian audiometrik dan soal selidik digunakan untuk menentukan status pendengaran dan maklumat daripada responden. Keputusan kajian menunjukkan bahawa kelaziman HL adalah $73.3 \%$ dan kelaziman kecelaan pendengaran adalah 23.3\%. Pekerja lelaki (63.0\%) mempunyai kelaziman HL yang lebih tinggi daripada pekerja wanita (36.4\%). Purata tahap ambang pendengaran responden HL adalah lebih tinggi daripada responden berpendengaran normal. Dalam kalangan pekerja yang berpengalaman bekerja lebih daripada 10 tahun, $80 \%$ daripada mereka menghidapi HL. Terdapat perkaitan antara pengalaman kerja dengan keadaan pendengaran (normal, tidak bilateral dan bilateral HL) secara statistik, $\chi(4)=10.51, \mathrm{p}=0.033$, dengan kolerasi Kendall tau-c menunjukkan $(\mathrm{p}=0.18)$ perhubungan yang positif dan lemah. Kes HLKP yang paling tinggi adalah pada frekuensi 4 dan $6 \mathrm{kHz}$. Klasifikasi tahap kecacatan pendengaran oleh Pertubuhan Kesihatan Sedunia dan Peraturan Kilang dan Jentera (Pendedahan Bunyi Bising) 1989 menunjukkan tahap kecacatan pendengaran responden adalah ringan kepada sederhana dan keputusan kajian berdasarkan kedua-dua piawaian tidak banyak berbeza (masing-masing 8.9\% dan 6.9\%). Kesimpulannya, kelaziman kehilangan pendengaran dan kecelaan pendengaran dalam kalangan pekerja sektor pengilangan adalah tinggi. Faktor yang berkemungkinan mempengaruhi HL adalah umur, lelaki, gaji bulanan serta pengalaman kerja.

Kata kunci: Kehilangan pendengaran akibat bunyi bising; kelaziman; pekerja pembuatan; tahap kecacatan pendengaran; ujian audiometrik 


\section{INTRODUCTION}

Technology advancement has changed the traditional methods of doing work and hence has increased productivity. However, noise, a by-product of such advancement has been identified to affect the human hearing capability (Basu 2010). Noise induced hearing loss (NIHL) is undoubtedly prevalent in industrial countries (Reddy et al. 2012), with no exception for Malaysia as manufacturing industry is the major sector in this country. Despite the existence of many other industrial hazards, none of it so common and widespread like noise pollution (Maisarah 1993).

NIHL is characterized as sensorineural, bilateral type of hearing loss which affects the function of cochlear due to prolonged and cumulative noise exposure (DOSH 2010; El Dib et al. 2012; Reddy et al. 2012). Hearing loss is one of the most severe and highly occurred sensory deficits in human populations (Mathers et al. 2000). According to the new estimates of World Health Organization (WHO) on the magnitude of disabling hearing loss, more than 250 million people around the world are affected in 2000 and has since increased to 360 million people in 2012 (WHO 2012). About one third of people aged more than 65 years are affected in disabling hearing loss and it is particularly highest in South Asia, Asia Pacific and Sub-Saharan Africa. Factories and Machinery Act (FMA) defines hearing impairment as an average permanent hearing threshold level (HTL) of an employee at $0.5 \mathrm{k}, 1 \mathrm{k}, 2 \mathrm{k}$ and $3 \mathrm{kHz}$ which is shifted by $25 \mathrm{~dB}$ or more compared to the standard audiometric reference level. It differs from the WHO definition, in which hearing impairment refer to average of HTL for frequencies $0.5 \mathrm{k}, 1 \mathrm{k}, 2 \mathrm{k}$ and $4 \mathrm{kHz}$ which is shifted $25 \mathrm{~dB}$ or more. In addition, WHO classify degree of hearing impairment into none, slight, moderate, severe and profound level. However, no classification of degree of hearing loss or hearing impairment was available for FMA at the moment.

For the last 27 years, Factories and Machinery (Noise Exposure) Regulation 1989 demanded all workers with workplace noise exposure of $85 \mathrm{~dB}$ or more need to be protected. In Malaysia, there were 2648 cases of occupational disease (OD) and poisoning cases in 2014, where 1563 cases of investigated OD were of noise induced hearing loss (NIHL) which was the commonest OD experienced by Malaysian workers $(78.1 \%)$ as compared with other diseases (DOSH 2014). According to a study on burden of NIHL among manufacturing workers in Malaysia, incidence risk of NIHL per 100,000 manufacturing workers projected to be $8 \%$. The highest risk and incidence was among the motor vehicle parts industry (32\%), followed by tobacco industry $(23 \%)$ and fabricated metal industry (23\%) (Tahir et al. 2014). This study aimed to investigate the prevalence of hearing loss (HL) as evidence to promote the hearing conservation program in the manufacturing industry of Malaysia. In addition, degree of hearing loss and hearing impairment were calculated for FMA by following the threshold categories as set by WHO classification.

\section{MATERIALS AND METHODS}

\section{STUDY DESIGN AND RESPONDENTS}

This is a cross-sectional study which used baseline data of a Solomon four-group study aimed to increase the hearing protection devices use among manufacturing workers in small medium enterprises in Selangor. A list of Small Medium Enterprises (SMEs) of medium size manufacturing industries in Selangor was obtained from SME Corporation Sdn. Bhd. Manufacturing companies will be included on voluntarily basis. Inclusion criteria for this study was adult worker, 18 years old and above, with workplace noise exposure of $85 \mathrm{~dB}$ and above. With assistant from management of the manufacturing factories, a name list of workers who was known to be exposed to noise level of $85 \mathrm{~dB}$ and above was used to randomly select study respondents. In the baseline data, 146 manufacturing workers were involved with audiometric testing as part of the hearing protection intervention. These 146 workers were recruited to determine the prevalence of HL among manufacturing workers. Manufacturing factories that volunteered for this study comprised of air-conditioning manufacturers and auto mobile parts manufacturers.

\section{QUESTIONNAIRE AND AUDIOMETRIC TEST}

Respondents were required to answer a questionnaire developed in English and Malay language on sociodemographics and occupational information. Questionnaires were completed in a classroom setting with presence of two researchers to ensure that respondents fully understand the questions. Prior to audiometric test, respondents were asked if they experienced any accident affecting ability of hearing, or any inflammation in both ears at the time of interview. Respondents with such conditions were not included in this study.

Respondent underwent pure tone audiometry to determine their hearing status early morning before they start work in the production floor. Audiometric testing complied with Regulation 20 and 26 of requirement of Factories and Machinery (Noise Exposure) Regulations 1989. Respondents were advised to be free from noisy environment for at least $14 \mathrm{~h}$ before audiometric test was performed. All audiometric tests were conducted by a trained technician under supervision of registered occupational health doctor, using a duly calibrated portable diagnostic audiometer, Amplivox 240, with TDH49P headset. Tests were done in a calibrated silent cabin which was transported to the manufacturing factories, placing in a quiet room away from the noise sources. Calibration carried out for both audiometer and silent cabin meet the requirement of Second Schedule, Regulation 20(4)(c) of Factories and Machinery (Noise Exposure) Regulations 1989.

Recommended procedure for pure tone air conduction audiometry by British Society of Audiology was referred for audiometric testing procedures. Respondents were asked to press the response switch whenever he heard a tone from the headset. The lowest audible tone heard at 
each frequency was recorded as the hearing threshold level (HTL). The HTLs of each ear was measured at frequencies $0.5 \mathrm{k}, 1 \mathrm{k}, 2 \mathrm{k}, 3 \mathrm{k}, 4 \mathrm{k}$ and $6 \mathrm{kHz}$. HTLs were determined by screening the right ear first. Beginning the test with $1 \mathrm{kHz}$ at $40 \mathrm{~dB}$, the tone was gradually decrease incrementally by 10 $\mathrm{dB}$ until there was no response elicited by the respondents. At the level where there was no more response, the tone was increased incrementally by $5 \mathrm{~dB}$ until there was a response. The lowest sound tone heard was taken as the HTL. This process was repeated for $2 \mathrm{k}, 3 \mathrm{k}, 4 \mathrm{k}, 6 \mathrm{k}$ and $0.5 \mathrm{kHz}$. Similarly, the left ear testing followed as per procedure (British Society of Audiology 2011).

\section{OPERATIONAL DEFINITIONS}

Definitions below were according to Factories and Machinery (Noise Exposure) Regulation 1989. Hearing conditions in this study were divided into the following classifications:

Normal Hearing: Air conduction hearing threshold levels is $<25 \mathrm{~dB}$ at all test frequencies $(0.5 \mathrm{k}, 1 \mathrm{k}, 2 \mathrm{k}, 3 \mathrm{k}, 4 \mathrm{k}$ and
$6 \mathrm{kHz})$; Hearing Loss: Air conduction hearing threshold levels is $\geq 25 \mathrm{~dB}$ at any frequency tested $(0.5 \mathrm{k}, 1 \mathrm{k}, 2 \mathrm{k}$, $3 \mathrm{k}, 4 \mathrm{k}$ and $6 \mathrm{kHz}$ ); and Hearing Impairment: Arithmetic average of the permanent hearing threshold level of an employee at $0.5 \mathrm{k}, 1 \mathrm{k}, 2 \mathrm{k}, 3 \mathrm{kHz}$ which is shifted by $25 \mathrm{~dB}$ or more compared to the standard audiometric reference level.

\section{STATISTICAL ANALYSIS AND ETHICAL ISSUE}

Statistical Package for Social Sciences (SPSS) 21.0 was used for statistical analysis in this study. Statistical significance was set at $p<0.05$ level. The research protocol was approved by Research Ethics Committee of Universiti Putra Malaysia.

\section{RESULTS}

\section{BACKGROUND OF THE RESPONDENTS}

Socio-demographics of the respondents were shown in Table 1. Among 146 respondents enrolled in this study,

TABLE 1. Social demographics of respondents and respective average hearing threshold levels for right and left ears

\begin{tabular}{|c|c|c|c|c|}
\hline \multirow[t]{2}{*}{ Variables } & \multirow[t]{2}{*}{$\mathrm{N}$} & \multirow[t]{2}{*}{$\%$} & \multicolumn{2}{|c|}{ Average hearing threshold level, $\mathrm{dB}$} \\
\hline & & & Right ear & Left ear \\
\hline \multicolumn{5}{|l|}{ Gender } \\
\hline Male & 135 & 92.5 & $19.43(9.66)$ & $19.35(9.15)$ \\
\hline Female & 11 & 7.5 & $13.56(5.38)$ & $14.62(9.38)$ \\
\hline \multicolumn{5}{|l|}{ Race } \\
\hline Malay & 136 & 93.2 & $18.53(9.16)$ & $18.73(9.34)$ \\
\hline Chinese & 8 & 5.5 & $24.27(13.72)$ & $23.54(7.29)$ \\
\hline Indian & 1 & 0.7 & 34 & 22 \\
\hline Others & 1 & 0.7 & 23 & 16 \\
\hline \multicolumn{5}{|l|}{ Education level } \\
\hline Primary School & 3 & 2.1 & $17.78(14.94)$ & $16.39(11.82)$ \\
\hline Secondary School & 117 & 80.1 & $19.53(9.64)$ & $19.29(9.05)$ \\
\hline Diploma & 22 & 15.1 & $17.20(8.88)$ & $17.92(9.98)$ \\
\hline Undergraduate Degree & 3 & 2.1 & $11.67(1.67)$ & $16.39(13.24)$ \\
\hline Doctorate Degree & 1 & 0.7 & 20 & 23 \\
\hline \multicolumn{5}{|l|}{ Work position } \\
\hline Operator/General worker & 64 & 43.8 & $19.39(9.88)$ & $20.03(10.49)$ \\
\hline Supervisor & 32 & 21.9 & $20.29(10.28)$ & $20.29(8.49)$ \\
\hline Executive & 9 & 6.2 & $16.94(9.19)$ & $16.94(9.19)$ \\
\hline Others & 41 & 28.1 & $17.78(8.49)$ & $17.78(8.49)$ \\
\hline \multicolumn{5}{|l|}{ Monthly income (RM) } \\
\hline$\leq 900$ & 14 & 9.6 & $18.39(8.98)$ & $17.08(11.32)$ \\
\hline $901-1500$ & 62 & 42.5 & $18.58(8.72)$ & $19.99(9.63)$ \\
\hline $1501-3000$ & 61 & 41.8 & $19.33(10.06)$ & $18.10(8.11)$ \\
\hline$>3000$ & 9 & 6.2 & $20.37(12.98)$ & $21.11(10.34)$ \\
\hline \multicolumn{5}{|l|}{ Work Duration } \\
\hline$<35$ & 10 & 6.8 & $14.25(6.82)$ & $14.50(7.91)$ \\
\hline $35-40$ & 24 & 16.4 & $18.44(8.94)$ & $19.58(8.59)$ \\
\hline $41-48$ & 48 & 32.9 & $20.69(10.05)$ & $20.35(10.38)$ \\
\hline$>48$ & 64 & 43.8 & $18.65(9.57)$ & $18.45(8.63)$ \\
\hline \multicolumn{5}{|l|}{ Shift work } \\
\hline Shift worker & 40 & 27.4 & $17.06(9.27)$ & $17.40(9.55)$ \\
\hline Non-shift worker & 106 & 72.6 & $19.71(9.56)$ & $19.59(9.07)$ \\
\hline \multicolumn{5}{|l|}{ Smoking Status } \\
\hline Never & 41 & 28.1 & & \\
\hline Former smoker & 32 & 21.9 & & \\
\hline Smoker & 73 & 50.0 & & \\
\hline
\end{tabular}


92.5\% was male and $7.5 \%$ was female. Age of the respondents ranged from 19 to 58 , with mean age 34.90 \pm 8.52 . Majority of respondents in this study were Malays (93.2\%) and was dominant by operator or general workers $(43.8 \%)$. About $80 \%$ of the respondents had education up to secondary school level. Monthly income of the respondents was mainly fall in RM901-1500 (42.5\%) and RM1501$3000(41.8 \%)$ categories, followed by $\leq$ RM900 (9.6\%) and >RM3000 (6.2\%). It was observed that $112(76.7 \%)$ respondents were working more than $40 \mathrm{~h}$ per week, where $48(32.9 \%)$ worked overtime (41-48 h per week) and 64 (43.8\%) had extended overtime. Average HTLs (0.5 k - 6 $\mathrm{kHz}$ ) for male workers were higher compared to female workers for left and right ears.

\section{PREVALENCE OF HEARING LOSS AND HEARING IMPAIRMENT}

Prevalence of hearing loss was $73.3 \%$ and hearing impairment was $23.3 \%$. Comparison between genders showed that male workers $(63.0 \%)$ had higher prevalence of hearing loss than female workers (36.4\%). Prevalence of hearing impairment was $24.4 \%$ for male workers and $9.1 \%$ for female workers. In addition, prevalence of bilateral hearing loss was 50\% and prevalence of bilateral hearing impairment was $8.2 \%$. Prevalence of hearing loss at right or left ear was as shown in Table 2.

\section{MEAN HEARING THRESHOLD LEVELS AND FREQUENCIES}

Respondents with hearing loss at each frequency ( 0.5 to 6 $\mathrm{kHz}$ ) were identified and illustrated in Table 3 . The mean HTLs for respondents with hearing loss were ranged from 25.85-41.92 dB whereas mean HTLs for respondents with normal hearing ranged from 11.26-15.51 dB. Highest number of hearing loss cases were found at $4 \mathrm{kHz}(63$ cases) and $6 \mathrm{kHz}$ (66 cases). Respondents were grouped into two categories based on their hearing condition (Table 4). Respondents with at least one hearing loss at any frequency were considered as hearing loss. One sample independent t-test was done to compare mean HTLs of respondents with normal hearing and respondents with HL. Mean HTLs of HL respondents were significantly higher than mean HTLs of respondents with normal hearing at all frequencies. Mean HTLs for respondents with normal hearing ranged from 7.56-13.59 dB whereas for $\mathrm{HL}$ respondents, it ranged from 17.38-28.27 dB. Higher mean HTLS were observed at high frequencies such as 4 and 6 $\mathrm{kHz}$, which were ranged from $26.78-28.27 \mathrm{~dB}$ as shown.

\section{DEGREE OF HEARING IMPAIRMENT AND HEARING LOSS}

Based on the WHO classification for hearing impairment, $8.9 \%$ of the respondents had slight to moderate hearing impairment at better ear and $21.9 \%$ of them had slight to moderate hearing impairment at worse ear (Table 5). For

TABLE 2. Distribution of respondents with hearing loss or hearing impairment

\begin{tabular}{lcccc}
\hline \multirow{2}{*}{ Hearing condition } & \multicolumn{4}{c}{ Total respondents, N $(\%)$} \\
\cline { 2 - 5 } & Right ear & Left ear & Non-bilateral & bilateral \\
\hline Hearing loss & $91(62.3)$ & $89(61.0)$ & $34(23.3)$ & $73(50.0)$ \\
Hearing impairment & $25(17.1)$ & $21(14.4)$ & $22(15.1)$ & $12(8.2)$ \\
\hline
\end{tabular}

*Respondents with at least one hearing loss at any frequency were considered as hearing loss

TABLE 3. Mean hearing threshold levels at respective frequencies for respondents with normal hearing or hearing loss at the respective frequencies

\begin{tabular}{cccc}
\hline Frequencies $(\mathrm{Hz})$ & Normal & Hearing loss \\
\hline Right ear & Mean HTLs , dB (SD) & $\mathrm{N}$ & Mean HTLs , dB (SD) \\
500 & $15.51(4.04)$ & 108 & $31.32(9.84)$ \\
1000 & $13.43(4.84)$ & 118 & $33.21(11.96)$ \\
2000 & $11.61(5.83)$ & 115 & $31.29(8.06)$ \\
3000 & $11.26(6.52)$ & 111 & $33.71(9.58)$ \\
4000 & $11.69(6.78)$ & 83 & $35.71(11.74)$ \\
6000 & $11.86(6.56)$ & 94 & $41.92(15.79)$ \\
Left ear & & 117 & $28.79(6.90)$ \\
500 & $14.87(4.62)$ & 125 & $25.85(6.50)$ \\
1000 & $13.44(5.66)$ & 114 & $28.75(5.54)$ \\
3000 & $11.89(6.11)$ & 97 & $29.59(10.66)$ \\
4000 & $12.94(6.40)$ & 90 & $34.50(12.86)$ \\
6000 & $12.50(6.33)$ & 80 & $37.20(14.47)$ \\
\hline
\end{tabular}

*Normal: There is no hearing loss at the stated frequencies

*Hearing loss: There is hearing loss ( $\geq 25 \mathrm{~dB}$ ) at the stated frequencies

e.g. 108 respondents had normal hearing at $500 \mathrm{~Hz}$ and 38 respondents had hearing loss at $500 \mathrm{~Hz}$ 
TABLE 4. Comparison of mean average HTLs of $0.5-6 \mathrm{kHz}$ for respondents grouped under normal hearing or hearing loss categories

\begin{tabular}{|c|c|c|c|c|c|}
\hline \multirow[t]{2}{*}{ Frequency $(\mathrm{Hz})$} & \multicolumn{2}{|c|}{ Mean HTL, dB (SD) } & \multirow{2}{*}{$95 \% \mathrm{CI}$} & \multirow{2}{*}{$t(d f)$} & \multirow{2}{*}{$p$ value } \\
\hline & Normal $(n=39)$ & Hearing loss $(n=107)$ & & & \\
\hline \multicolumn{6}{|l|}{ Right ear } \\
\hline 500 & $13.59(4.28)$ & $21.82(9.58)$ & $5.95-10.51$ & 7.15 (138.16) & $<0.001$ \\
\hline 1000 & $11.41(5.25)$ & $19.35(10.90)$ & $5.27-10.60$ & $5.89(133.30)$ & $<0.001$ \\
\hline 2000 & $8.46(5.98)$ & $18.46(10.22)$ & $7.27-12.72$ & $7.27(115.22)$ & $<0.001$ \\
\hline 3000 & $7.56(7.42)$ & $19.95(11.79)$ & $9.13-15.65$ & $7.53(107.42)$ & $<0.001$ \\
\hline 4000 & $9.10(6.27)$ & $26.78(14.59)$ & $12.80-24.65$ & $6.25(144)$ & $<0.001$ \\
\hline 6000 & $8.85(6.54)$ & $27.57(18.25)$ & $14.67-22.78$ & $9.13(144)$ & $<0.001$ \\
\hline \multicolumn{6}{|l|}{ Left ear } \\
\hline 500 & $12.82(3.94)$ & $19.39(7.82)$ & $4.62-8.52$ & 6.67 (129.68) & $<0.001$ \\
\hline 1000 & $10.90(5.37)$ & $17.38(7.99)$ & $3.75-9.22$ & $4.69(144)$ & $<0.001$ \\
\hline 2000 & $8.46(5.98)$ & $18.18(8.81)$ & $7.18-12.26$ & $7.59(99.56)$ & $<0.001$ \\
\hline 3000 & $10.13(7.21)$ & $22.99(12.03)$ & $9.62-16.11$ & $7.85(112.70)$ & $<0.001$ \\
\hline 4000 & $9.87(5.90)$ & $26.78(15.51)$ & $13.40-20.41$ & $9.54(143.69)$ & $<0.001$ \\
\hline 6000 & $9.49(7.50)$ & $28.27(16.50)$ & $14.84-22.73$ & $9.41(137.20)$ & $<0.001$ \\
\hline
\end{tabular}

*Normal: $<25 \mathrm{~dB}$ for average HTL $(0.5-6 \mathrm{kHz})$

*Hearing loss: $\geq 25 \mathrm{~dB}$ for average HTL $(0.5-6 \mathrm{kHz})$

TABLE 5. Distribution of degree of hearing impairment by FMA and WHO classification

\begin{tabular}{|c|c|c|c|c|c|}
\hline & \multicolumn{5}{|c|}{$\begin{array}{l}\text { FMA hearing impairment, } \mathrm{N}(\%) \\
\text { (Average of } 0.5,1 \mathrm{k}, 2 \mathrm{k}, 3 \mathrm{kHz} \text { ) }\end{array}$} \\
\hline & $\begin{array}{c}\text { No } \\
\leq 25 \mathrm{~dB}\end{array}$ & $\begin{array}{l}\text { Slight } \\
26-40 \mathrm{~dB}\end{array}$ & $\begin{array}{l}\text { Moderate } \\
41-60 \mathrm{~dB}\end{array}$ & $\begin{array}{l}\text { Severe } \\
61-80 \mathrm{~dB}\end{array}$ & $\begin{array}{l}\text { Profound } \\
\geq 81 \mathrm{~dB}\end{array}$ \\
\hline Better ear & $136(93.2)$ & $8(5.5)$ & $2(1.4)$ & - & - \\
\hline \multirow[t]{3}{*}{ Worse ear } & $118(80.8)$ & $22(15.1)$ & $6(4.1)$ & - & - \\
\hline & \multicolumn{5}{|c|}{$\begin{array}{l}\text { WHO hearing impairment, N (\%) } \\
\text { (Average of } 0.5,1 \mathrm{k}, 2 \mathrm{k}, 4 \mathrm{kHz} \text { ) }\end{array}$} \\
\hline & $\begin{array}{l}\mathrm{No}^{\mathrm{a}} \\
\leq 25 \mathrm{~dB}\end{array}$ & $\begin{array}{c}\text { Slight }^{\mathrm{b}} \\
26-40 \mathrm{~dB}\end{array}$ & $\begin{array}{l}\text { Moderate }^{c} \\
41-60 \mathrm{~dB}\end{array}$ & $\begin{array}{l}\text { Severe }^{\mathrm{d}} \\
61-80 \mathrm{~dB}\end{array}$ & $\begin{array}{l}\text { Profound }^{\mathrm{e}} \\
\geq 81 \mathrm{~dB}\end{array}$ \\
\hline Better ear & $133(91.1)$ & $12(8.2)$ & $1(0.7)$ & - & - \\
\hline Worse ear & $114(78.1)$ & $26(17.8)$ & $6(4.1)$ & - & - \\
\hline
\end{tabular}

*According to WHO classification of degree of hearing impairment at better ear:

${ }^{a}$ No or very slight hearing problems. Able to hear whisper

${ }^{\mathrm{b}}$ Able to hear and repeat words spoken in normal voice at 1 metre

${ }^{\mathrm{c}}$ Able to hear and repeat words using raised voice at 1 metre

${ }^{\mathrm{d}}$ Able to hear some words when shouted into better ear

${ }^{\mathrm{e}}$ Unable to hear and understand even a shouted

FMA classification, $6.9 \%$ of the respondents had slight to moderate hearing impairment at better ear, whereas for worse ear $19.2 \%$ of the respondents suffered from slight to moderate hearing impairment. Classifications of WHO were used to express the degree of hearing loss among 146 respondents. Average HTLs of $0.5 \mathrm{k}, 1 \mathrm{k}, 2 \mathrm{k}, 3 \mathrm{k}, 4 \mathrm{k}, 6 \mathrm{kHz}$ ranged from $1.67-50.83 \mathrm{~dB}$. It was observed that $13.7 \%$ of respondents suffered from mild to moderate hearing loss at better ear and $30.9 \%$ had mild to moderate hearing loss at worse ear (Table 6).

\section{BILATERAL HEARING LOSS AND EMPLOYMENT YEARS}

Respondents were categorized into three groups of employment years (Table 7) which were 0-10 years
$(63.0 \%), 11-20$ years $(22.6 \%)$ and $21-30$ years $(14.4 \%)$ of working experience in the current company. Through Pearson Chi-Square test, there was a statistically significant association between employment years and hearing condition, $\chi(4)=10.51, p=0.033$. The level of association as shown by Kendall tau-c correlation was positive and weak $(p=0.18)$.

\section{DISCUSSION}

According to findings of studies in various countries, hearing loss and hearing impairment were positively related to age, male sex and middle- and low-income regions, previous and current exposure time to high noise 
TABLE 6. Distribution of respondents according to degree of hearing loss

\begin{tabular}{cccccc}
\hline \multicolumn{5}{c}{ Degree of hearing loss } \\
& Normal $<25 \mathrm{~dB}$ & Mild & Moderate & Severe & Profound \\
& & $25-40 \mathrm{~dB}$ & $41-60 \mathrm{~dB}$ & $61-80 \mathrm{~dB}$ & $\geq 81 \mathrm{~dB}$ \\
Better ear & $126(86.3 \%)$ & $19(13.0 \%)$ & $1(0.7 \%)$ & - & - \\
Worse ear & $101(69.2 \%)$ & $36(24.7 \%)$ & $9(6.2 \%)$ & - \\
Right ear & $114(78.1)$ & $26(17.8)$ & $6(4.1)$ & \\
Left ear & $113(77.4)$ & $29(19.9)$ & $4(2.7)$ & \\
\hline
\end{tabular}

TABLE 7. Chi-square association between hearing condition and employment years

\begin{tabular}{|c|c|c|c|c|c|}
\hline \multirow{2}{*}{$\begin{array}{c}\text { Employment } \\
\text { years }\end{array}$} & \multicolumn{4}{|c|}{ Hearing condition, $\mathrm{N}(\%)$} & \multirow{2}{*}{$\begin{array}{c}\text { Chi-square (df) } \\
p \text { value }\end{array}$} \\
\hline & Normal & $\begin{array}{c}\text { Non-bilateral } \\
\text { HL }\end{array}$ & $\begin{array}{c}\text { Bilateral } \\
\text { HL }\end{array}$ & Total & \\
\hline $0-10$ & $29(31.5)$ & $25(27.2)$ & $38(41.3)$ & $92(100.0)$ & $10.51(4), 0.033$ \\
\hline $11-20$ & $6(18.2)$ & $8(24.2)$ & $19(57.6)$ & $33(100.0)$ & \\
\hline $21-30$ & $4(19.0)$ & $1(4.8)$ & $16(76.2)$ & $21(100.0)$ & \\
\hline
\end{tabular}

*Kendall's Tau-c $=0.180, p=0.005$

levels (Reddy et al. 2012; Stevens et al. 2013). In light of these influencing factors, analysis regarding age, gender, monthly salary and employment years were done.

Age of the respondents ranged from 19 to 58 years old, with mean age $34.90 \pm 8.52$ years old. Age of the respondents was controlled below 65 years old to avoid the possible occurrence of presbycusis, which is a condition of hearing loss that gradually occurs when people grow older. According to World Health Organization, one third of people more than 65 years old are affected by disabling hearing loss. Prevalence for this age group is highest in South Asia, Asia Pacific and sub-Saharan Africa (WHO 2012).

As shown in Table 1, about half of the respondents were operator or general workers and $80 \%$ of them had education up to secondary school level. More than $80 \%$ of them earned RM900 to RM3000 a month and 76.7\% respondents worked more than $40 \mathrm{~h}$ per week. HTLs for both ears for secondary school level group were found to be higher than that of other workers with different education levels. Furthermore, HTLs for operator, general workers and supervisor were also higher than executive and other workers. Operator, general workers and supervisors normally work more than $40 \mathrm{~h}$ per week near noise sources. Thus, it can be assumed that low socioeconomic groups were at greater risk of developing hearing loss, which is similar with findings from Filza Ismail et al. (2013).

Male workers had higher prevalence of hearing loss and hearing impairment than female workers. Findings were supported by several studies in assessing hearing loss among workers (Feder et al. 2015; Hasson et al. 2011; Tahir et al. 2014). Possible reasons referring to previous literatures include greater noise exposure in occupational settings, different exposure to smoking, atheroscelerosis, or other potential risk factors for hearing loss (Cruickshanks et al. 1998; Siegelaub et al. 1974) such as inherent anatomical and physiological differences which influence the basic auditory sensitivity and susceptibility to hearing loss, including levels of endogenous steroid hormones (estrogen and progesterone) on the cochlear response to noise (McFadden 2000). According to the findings of the study conducted by McFadden (2000), there was a strong link between levels of endogenous steroid hormones and individual's susceptibility to NIHL. Estradiol was found to be protective against NIHL and females had higher and more variable levels of serum estradiol than males. Estradiol was believed to have certain effect at the level of the stria vascularis of the ears, such as marginal cells or vascular tissue.

Table 7 shows that prevalence of unilateral and bilateral hearing loss of workers with $0-10$ years (68.5\%) of employment years in the current company was lesser as compared to $11-20$ years $(81.8 \%)$ and $21-30$ years $(81 \%)$. Thus, hearing problems of the workers after more than 10 years of working in high noise environment were significant since more than $80 \%$ of them suffered from hearing loss. This was in accordance with other studies that workers developed permanent hearing loss if occupational noise exposures were more than 10 years (Geovanna et al. 2014). In fact, other researchers stated that hearing losses at $3 \mathrm{k}, 4 \mathrm{k}$ and $6 \mathrm{kHz}$ for NIHL will finally reach a maximum level in 10 to 15 years under stable noise exposure condition (Bergström \& Nyström 2009; Dobie 1990). With all these findings, hearing loss or hearing impairment in this study were found to be positively related to age, male sex, monthly salary and employment years as discussed earlier. However, further analysis need to be done to fully understand about the relationships between them. 
Prevalence of hearing loss (73.3\%) for manufacturing workers in this study was considered high compared to other local studies of different industries such as $57.0 \%$ in quarry workers (Filza Ismail et al. 2013), vector control workers 26.0\% (Masilamani et al. 2014). When compared to the hearing loss prevalence of workers in other countries, the prevalence of respondents in this study showed a more severe condition as it was higher. Prevalence of hearing loss in other countries included $22 \%$ among New York farmers (Hwang et al. 2001), 56.8\% among Nigerian steel rolling mill workers (Ologe et al. 2006), 44.2\% among Brazilian metallurgical workers (Geovanna et al. 2014) and 47.0\% among Tanzanian miners (Musiba 2015).

Through observation, respondents often exposed to a variety of manufacturing processes, machinery and equipment which produce high noise levels and these can affect the ear. For example, high noise was generated by dumping sheared parts into racks or metal recycling bins, stacking sheet metal, small and medium stamping machines. Daily sources of man-made noises such as from grinding, shearing, punching, forming, hammering activities in a manufacturing factory are common. Hearing loss seems not to be taken serious by some of the workers because they feel that it is not a life-threatening injury and some even thought that it is curable (Maisarah 1993; Rus et al.2008). Workers were always unaware of their hearing problems if it did not affect their capability of listening to speeches.

Exposure to excessive noise at workplace affect higher frequencies more, with most of the hearing loss cases happened to study respondents at frequencies 4 and $6 \mathrm{kHz}$ as shown in Table 3. The destructive nature of excessive loud noise to high frequencies was very well studied. NIHL primarily affects the high frequencies region, such as $3 \mathrm{k}, 4$ $\mathrm{k}$ and $6 \mathrm{kHz}$ and then spread to lower frequencies such as $0.5 \mathrm{k}, 1 \mathrm{k}$ and $2 \mathrm{kHz}$ (Chen \& Tsai 2003; Kitcher et al. 2014; Maisarah 1993; Ologe et al. 2006). Although at the moment we could not conclude that hearing loss experienced were NIHL, there is possibility that our respondents may suffer from NIHL since some of them do have some of the characteristics of NIHL. Further investigation including pure tone bone conduction audiometry, tympanometry or otoscopy are needed for confirmation of NIHL occurrence among the study respondents.

There is a diversity of definitions of hearing impairment worldwide, thus comparison among studies is difficult and invalid. In this study, WHO classification was used to classify hearing impairment according to the average HTLs in the better hearing ear. In Factories and Machinery (Noise Exposure) Regulation 1989, no specific classification was found for degree of hearing impairments. There is a need for a common language among professionals and meaningful interpretations for clients, thus a classification on hearing impairment in Malaysia should be introduced. Hence, the degree of hearing impairment among respondents were calculated based on the range of HTLs of WHO classification except average HTLs of frequencies $0.5 \mathrm{k}, 1 \mathrm{k}, 2 \mathrm{k}$ and $3 \mathrm{kHz}$ were used. Although different frequencies were used, there was not much difference observed in both standards. A total of $6.9 \%$ respondents based on FMA classification and $8.9 \%$ respondents based on WHO classification suffered from slight to moderate hearing impairment. These respondents might experience some difficulties in hearing conversations but they are still fit for communications (WHO 2012). None of the respondents was experiencing severe or profound hearing condition. These findings showed that most of the study respondents were at early stages of hearing impairment which is similar with study done by Filza Ismail et al. (2013).

\section{CONCLUSION}

Prevalence of hearing loss and hearing impairment among manufacturing workers were high as compared to other industries locally and internationally. Further investigations are necessary to determine whether study respondents were suffering from NIHL, as well as to clarify the relationship of hearing loss and hearing impairment with age, male sex, monthly salary and employment years. Hearing conservation program should be promoted to reduce NIHL. A classification of degree of hearing impairment should be created in Malaysia to interpret the severity of hearing loss affecting speech understanding and communication.

\section{ACKNOWLEDGEMENTS}

The authors wish to thank all respondents involved, kind support from management of manufacturing factories for excellent assistance in this study. This study was funded by Putra Grant of Universiti Putra Malaysia (GPIPS/2013/9399831).

\section{REFERENCES}

Basu, D.K. 2010. Noise pollution in India. Journal of the Indian Medical Association 108(3): 139.

Bergström, B . \& Nyström, B. 2009. Development of hearing loss during long-term exposure to occupational noise a 20 -year follow-up study. Scandinavian Audiology 15(4): 227-234. doi:10.3109/01050398609042148.

British Society of Audiology. 2011. Pure-tone air-conduction and bone-conduction threshold audiometry with and without masking. Berkshire: British Society of Audiology. pp. 1-32.

Chen, J-D. \& Tsai, J-Y. 2003. Hearing loss among workers at an oil refinery in Taiwan. Archives of Environmental Health 58(1): 55-58. doi:10.3200/AEOH.58.1.55-58.

Cruickshanks, K.J., Wiley, T.L., Tweed, T.S., Klein, B.E., Klein, R., Mares-Perlman, J.a. \& Nondahl, D.M. 1998. Prevalence of hearing loss in older adults in Beaver Dam, Wisconsin. The epidemiology of hearing loss study. American Journal of Epidemiology 148(9): 879-886. doi:10.1093/oxfordjournals. aje.a009713.

Dobie, R.A. 1990. A method for allocation of hearing handicap. Otolaryngology-Head and Neck Surgery 103(5(Pt 1)): 733 739. 
DOSH. 2014. Occupational Diseases and Poisoning Investigation. Putrajaya: Department of Occupational Safety and Health, Ministry of Human Resource Malaysia. Accessed on 3 March 2016.

El Dib, R.P., Mathew, J.L. \& Martins, R.H.G. 2012. Interventions to promote the wearing of hearing protection. The Cochrane Database of Systematic Reviews 4 (January): CD005234. doi:10.1002/14651858.CD005234.pub5.

Factories and Machinery (Noise Exposure) Regulations. 1989. Malaysia: Federal Subsidiary Legislation.

Feder, K., Michaud, D., Ramage-morin, P., Mcnamee, J. \& Beauregard, Y. 2015. Health reports prevalence of hearing loss among Canadians aged 20 to 79 : Audiometric results from the 2012/2013 Canadian health measures survey. Health Reports 26(7): 18-25. doi:10.1017/CBO9781107415324.004.

Filza Ismail, Ahmad, Aziah Daud, Zaliha Ismail \& Baharudin Abdullah. 2013. Noise-induced hearing loss among quarry workers in a North-Eastern state of Malaysia: A study on knowledge, attitude and practice. Oman Medical Journal 28(5): 331-336. doi:10.5001/omj.2013.96.

Geovanna, K., Crispim, M. \& Ferreira, A.P. 2014. Incidence and prevalence of noise induced hearing loss in workers of a metallurgical company in Manaus - AM, Brazil. Incidência E Prevalência de Perda Auditiva Induzida Por Ruído Em 16(2): 1456-1462.

Hasson, D., Theorell, T., Wallén, M.B.,Leineweber, C. \& Canlon, B. 2011. Stress and prevalence of hearing problems in the Swedish working population. BMC Public Health 11: 30.

Hwang, S-a., Gomez, Ã.M.I., Sobotova, L., Stark, A.D., May, J.J. \& Hallman, E.M. 2001. Predictors of hearing loss in New York farmers. American Journal of Industrial Medicine 40: 23-31.

Kitcher, E.D., Ocansey, G., Abaidoo, B. \& Atule, A. 2014. Occupational hearing loss of market mill workers in the City of Accra, Ghana. Noise \& Health 16(70): 183-188. doi:10.4103/1463-1741.134919.

Maisarah, S.Z. 1993. The noise exposed factory workers: The prevalence of sensori-neural hearing loss and their use of personal hearing protection devices. Med. J. Malayisa 48: 280-285.

Masilamani, R., Abdul Rasib, Azlan Darus \& Anselm Su Ting. 2014. Noise-induced hearing loss and associated factors among vector control workers in a Malaysian state. Asia-Pacific Journal of Public Health/Asia-Pacific Academic Consortium for Public Health 26(6): 642-650. doi:10.1177/1010539512444776.

Mathers, C., Smith, A. \& Concha, M. 2000. Global burden of hearing loss in the year 2000. Global Burden of Disease 18(4): 1-30. http://www.who.int/healthinfo/statistics/ bod_hearingloss.pdf \nhttp://www.who.int/entity/healthinfo/ statistics/bod_hearingloss.pdf.

McFadden, S.L. 2000. Sex difference in susceptibility and resistance to noise-induced hearing loss in chinchillas. Storming Media Pentagon Reports, Washington, DC, no. Report number A676783.

Musiba, Z. 2015. The prevalence of noise-induced hearing loss among Tanzanian miners. Occupational Medicine 65(5): 386-390. doi:10.1093/occmed/kqv046.
Ologe, Foluwasayo E, Tanimola M Akande, and Toye G Olajide. 2006. Occupational noise exposure and sensorineural hearing loss among workers of a steel rolling mill. European Archives of Oto-Rhino-Laryngology: Official Journal of the European Federation of Oto-Rhino-Laryngological Societies (EUFOS): Affiliated with the German Society for Oto-RhinoLaryngology - Head and Neck Surgery 263(7): 618-621. doi:10.1007/s00405-006-0043-9.

Reddy, R.K., Welch, D., Thorne, P. \& Ameratunga, S. 2012. Hearing protection use in manufacturing workers: A qualitative study. Noise \& Health 14(59): 202-209. doi:10.4103/1463-1741.99896.

Rus, Razman Mohd, Aziah Daud, Kamarul Imran Musa and Lin Naing. 2008. Knowledge, attitude and practice of sawmill workers towards noise-induced hearing loss in Kota. Malaysian Journal of Medical Sciences 15(4): 28-34.

Siegelaub, A.B., Friedman, G.D.,Adour, K. \& Seltzer, C.C. 1974 Hearing loss in adults: Relation to age, sex, exposure to loud noise, and cigarette smoking. Archives of Environmental Health 29(2): 107-109.

Stevens, Gr., Flaxman, S., Brunskill, E., Mascarenhas, M., Mathers, C.D. \& Finucane, M. 2013. Global and regional hearing impairment prevalence: An analysis of 42 studies in 29 countries. European Journal of Public Health 23(1): 146-152. doi:10.1093/eurpub/ckr176.

Noraita Tahir, Syed Mohamed Aljunid, Jamal Hisham Hashim \& Jaseema Begum. 2014. Burden of noise induced hearing loss among manufacturing industrial workers in Malaysia. Iranian Journal of Public Health 43(3): 148-153.

WHO. 2013. Prevention of blindness and deafness. Grades of hearing impairment. Geneva: World Health Organization. Accessed on 29 February 2016. http://www.who.int/pbd/ deafness/hearing_impairment_grades/en/.

WHO. 2012. Global estimates on prevalence of hearing loss. Geneva: World Health Organization. Accessed on 29 February 2016. http://www.who.int/pbd/deafness/estimates.

Sam, W.Y., Anita, A.R., * Hayati, K.S., Haslinda, A. \& Lim, C.S. Department of Community Health

Faculty of Medicine and Health Sciences

Universiti Putra Malaysia

43400 UPM Serdang, Selangor Darul Ehsan Malaysia

Haslinda, A.

Department of Social \& Development Sciences

Faculty of Human Ecology

Universiti Putra Malaysia

43400 UPM Serdang, Selangor Darul Ehsan

Malaysia

*Corresponding author; email: anitaar@upm.edu.my

Received: 10 March 2016

Accepted: 16 May 2016 